\title{
Promoting the Peace: Queen Anne and the Public Thanksgiving at St Paul's Cathedral
}

\author{
Julie Farguson
}

On 7 July 1713 a 'Publick Thanksgiving' was held at St. Paul's Cathedral in London for the 'Blessings of Peace.' This event involved a grand procession from the Houses of Parliament to the Cathedral, a long religious service accompanied by music, followed in the evening by spectacular firework displays and other forms of celebration. Enormous crowds turned out to watch the processions, some paying to watch the festivities from balconies overlooking the proceedings, while others sat on specially prepared stands. ${ }^{2}$ Four thousand children from London charity schools were 'placed upon a machine in the Strand' and throughout the event they sang 'hymns of...p praise to God, for her Majesty' and the gift of peace. ${ }^{3}$ As the queen had issued a proclamation for a general thanksgiving, religious ceremonies were held in towns and cities all over the country. ${ }^{4}$ The form of service to be used for these ceremonies was dictated by the Church of England and authorised by Queen Anne who read the document before it was printed. ${ }^{5}$ These regional ceremonies were accompanied by civic festivities which brought local communities together, and generated outpourings of fidelity to the queen. At provincial gatherings aldermen and other civic dignitaries made speeches and drank loyal toasts to the 'Queen', the 'Peace' and the 'Protestant succession'. ${ }^{6}$ But not everyone was enamoured of the Peace Treaty. On the day of the St Paul's ceremony a number of Whigs resisted the

1 The service at St Paul's Cathedral was originally planned for 16 June. I would like to thank Dr Toby Barnard and Dr Hannah Smith for their assistance in the preparation of this chapter.

2 Daily Courant 4 July 1713: 3658; Evening Post 2-4 June 1713: 596; Evening Post 2 July 1713: 6o9; Post Boy, 7-9 July 1713: 2834 .

3 Post Boy, 7-9 July 1713: 2834; British Museum thereafter вм Mm, 2.106, engraved print.

4 A simple search on Solo (the online catalogue for the Bodleian Library, Oxford) and the British Library online catalogue produced 29 thanksgiving sermons from different parts of the country.

5 The National Archives SP/34/21/7 f. 14-15 Archbishop of Canterbury to Lord Dartmouth 7 April 1713; The National Archives, SP/34/21/9 Archbishop of Canterbury to Lord Dartmouth 8 April 1713 .

6 For examples see: Post Boy, 2-4 June 1713: 2819; Post Boy, 11-14 July 1713: 2836.

(C) KONINKLIJKE BRILL NV, LEIDEN, 2015 | DOI 10.1163/9789004304789_014 
royal call. Peers and Members of Parliament stayed away from the celebrations, and no doubt in the localities, other less prominent individuals also ignored the call to give thanks. ${ }^{7}$ These absences reflect the long-standing political controversies that surrounded the Peace Treaty and continuing animosity.

As the queen's health deteriorated political acrimony was also fuelled by the question of the succession. Political intrigue and subterfuges during the negotiations for the peace treaty had made many in both Houses of Parliament feel uneasy, and anxiety over the security of the Protestant succession reached a critical level in the summer of 1713. Both Anne's right to the throne and the Hanoverian succession were recognised in the treaty, but the queen and her Tory ministers were widely suspected of wishing to reinstate the Stuart heir to the throne-James Francis Edward; commonly known as the Pretenderand these misgivings were not without reason. Jacobite strength in Parliament was greater than in any House of Commons since the queen's accession, and Anne's chief minister, Robert Harley, the 1st earl of Oxford had needed Jacobite support to achieve his peace policy. ${ }^{8}$ On a trip to Paris, Oxford's political ally-Lord Bolingbroke - had attended the opera and been seen sitting in a box near the Pretender, news which quickly got back to London and caused outrage. ${ }^{9}$ Furthermore, with the tacit support of the government, Jacobite rebels flooded back into Britain. ${ }^{10}$ These and other, similar acts simply heightened the atmosphere of distrust. The leaders of the Whig party, realising they could not prevent the conclusion of the peace, sponsored a propaganda campaign to arouse the widest possible suspicion of the Tory ministry's future intentions towards the Protestant succession, once the Peace was concluded. These political manoeuvres simply exacerbated an already inflamed situation and undermined the authority of the Crown. With the Scots pushing for the dissolution of the union, the queen feared a civil war and others shared her concerns. ${ }^{11}$ Political factionalism had reached such a pitch that the British nation was threatened with destruction.

7 Donald Burrows, Handel and the English Chapel Royal (Oxford: Oxford University Press, 2005), 82 .

8 For an overview of the politics of Anne's later years see: Julian Hoppit, A Land of Liberty? England 1689-1727 (Oxford: Oxford University Press, 2000), 300-312.

Edward Gregg, Queen Anne (London, Boston and Henley: Routledge and Kegan Paul, 1980), 359; for the intricacies of the complex working relationship between Harley and Bolingbroke who oscillated between being close allies and rivals see: Sheila Biddle, Bolingbroke and Harley (London: Allen and Unwin, 1975).

10 Gregg, Anne, 363.

11 Gregg, Anne, 334, 367. 
Historians of British political history generally analyse the conclusion of the war and the signing of the peace treaty along with the furore over the succession in secular terms, focussing on debates in Parliament and the manoeuvrings of politicians and generals. The role of Queen Anne in all these processes has largely been disregarded; the political implications of the ceremonial aspects of the treaty ignored. This neglect is in keeping with a historiography that argues for decline during this period, not only in the culture of the court but also in terms of how the monarchy functioned. ${ }^{12}$ It also relates to long-standing scholarly assumptions about the secularisation of royal power in the eighteenth century. ${ }^{13}$ Consequently the religious dimension to the peace treaty-the public thanksgiving at St Paul's and the role Anne played both as an advocate and, in the end, a sort of virtual participant in the ceremony-has been overlooked. ${ }^{14}$

In the last few years, however, there has been a reversal in these historiographical trends. Older narratives of decline are being replaced by new perspectives. ${ }^{15}$ A growing awareness of the symbolic dimension to politics has revealed the continuing importance of courtly ceremonies and rituals as a means of not only presenting princely status and royal authority but also

12 Robert O. Bucholz, The Augustan Court: Queen Anne and the Decline of Court Culture (Stanford, California: Stanford University Press, 1993), passim; Kevin Sharpe, Rebranding Rule: the Restoration and Revolution Monarchy, 1660-1714 (New Haven and London: Yale University Press, 2013), 507-646 and the epilogue. According to Sharpe by the end of Anne's reign 'the monarchy as the affective centre of the nation was... moribund'... 'Representational monarchy perforce gave way to a fully rational public sphere': 676,680 .

13 Paul Kléber Monod, The Power of Kings: Monarchy and Religion in Europe, 1589-1715 (New Haven and London: Yale University Press 1999), 273-315. Monod acknowledges Anne's personal piety but suggests she was a 'rationalist', 293.

14 Sharpe, Rebranding Rule, Kevin Sharpe pays little attention to the public thanksgiving held during Anne's reign. He sees these ceremonies, in addition to being a thanksgiving to God, as 'an act of worship of the queen'. This assessment suggests these ceremonies were reinforcing divine-right notions of monarchical rule; see 620-21; quote, 620.

15 These include: The Princely Courts of Europe: Ritual, Politics and Culture under the Ancien Régime 1500-1750, ed. John Adamson (London: Seven Dials, Cassel \& Company, 2000); Tim Blanning, The Culture of Power and the Power of Culture: Old Regime Europe, 1660-1789 (Oxford: Oxford University Press, 2003); Jeroen Duindam, Vienna and Versailles: the Courts of Europe's Dynastic Rivals (Cambridge: Cambridge University Press, 2003); Queenship in Europe, 1660-1815: the Role of the Consort, ed. Clarissa Campbell Orr (Cambridge: Cambridge University Press, 2004); Julie Farguson, 'Art, Ceremony and the British Monarchy, 1689-1714' (DPhil diss., University of Oxford, 2013). 
in communicating with princes, courtiers and subjects on political matters. ${ }^{16}$ Running in parallel with this reassessment of court culture, a number of scholars have reconsidered the role of religion in the representation of royal power during the eighteenth century, and have argued that religion remained a 'vibrant force' at all European courts during this period. ${ }^{17}$ It is within these recent historiographical developments that my essay will be situated.

By re-examining the architectural setting for this event, along with the religious service and its music, this essay will demonstrate that-despite not being well enough to attend the service-Queen Anne used ceremonial performance as a means of asserting her political authority: to promote the peace, but also to publicise her desire for civic harmony and national unity. An underlying, but nonetheless important aim, which was expressed more subtly, was to distance herself from the Caesaro-papal style of monarchy practised by her father-James II - and stress her commitment to the Hanoverian succession. But to understand the significance of the 1713 ceremony we need to engage briefly with the history of public thanksgivings in England and examine how this ceremonial form was utilised by Queen Anne to mark military victories.

\section{The History of Public Thanksgivings in England and the New Arrangements}

Since medieval times St Paul's Cathedral had been used by monarchs for the celebration and commemoration of events deemed to be of national importance. ${ }^{18}$ Victory in battle was thought to be a blessing from God, and divine intervention in military affairs called for a powerful expression of communal gratitude. ${ }^{19}$ The most famous of these wartime ceremonies at St Paul's was the public thanksgiving led by Elizabeth I in 1588, to celebrate victory over the Spanish Armada. The tradition of thanksgiving continued under the Stuarts, albeit in a different architectural setting as by the 1620 s the three

16 For an overview of these historiographical shifts see: Michael Schaich, 'Introduction,' in Monarchy and Religion: The Transformation of Royal Culture in Eighteenth-Century Europe, ed. Michael Schaich (Oxford: Oxford University Press, 2007), 1-40.

17 Ibid.

18 David J. Crankshaw, 'Community, City and Nation, 1540-1714', in St Paul's: the Cathedral Church of London, ed. D. Keene et al. (New Haven and London: Yale University Press, 2004), 45-70.

19 Natalie Mears, 'Public Worship and Political Participation in Elizabethan England, Journal of British Studies 51 (2012): 4-25. 
institutions of government worshipped separately: the monarch at the Chapel Royal at Whitehall Palace, the House of Lords at Westminster Abbey, and the House of Commons at St Margaret's Church, Westminster. ${ }^{20}$ In the years following the Restoration of Charles II, a significant number of thanksgivings were held in response to military victories and the signing of peace treaties, most notably during the Nine Years' War (1688-97). Between 1689 and 1701 the Crown ordered seven public thanksgivings in connection with the war effort. Two were to give thanks for military victory (Boyne, 1690; Namur, 1695), five marked the safe return of the king at the end of the campaign season (1691-96) and one was staged to celebrate the Peace of Ryswick (1697). ${ }^{21}$ None of these, however, was held at St. Paul's although the new cathedral was being built, and by 1697 the building was ready enough to be used for religious services. ${ }^{22}$ Instead William and Mary continued to follow the old system, and they worshipped in the Chapel Royal. William followed the same pattern when he ruled alone after Mary's death in 1694. Once Anne had ascended the throne and Britain was again at war, the way military victories were celebrated changed completely.

The Crown had always chosen the events that warranted nationwide worship, and in the Tudor period they oversaw the production of approved prayers and special liturgies by Church of England clergymen. ${ }^{23}$ Similarly, the decision to hold a state thanksgiving outside the palace setting was the monarch's prerogative. Consequently, these ceremonies and their attendant processions came under the jurisdiction of the royal household and were organised by the Lord Chamberlain supported by officers from the College of Arms. ${ }^{24}$ Following allied victory at the battle of Vigo in October 1702, the queen announced there would be a public thanksgiving at St Paul's Cathedral and throughout

20 Burrows, Handel and the English Chapel Royal, 29. The last monarch to worship at St Paul's 'in state', prior to 1702, was James I. He attended a service at the old cathedral on $26 \mathrm{March}$ 1620. See: Lambeth Palace, Fulham Papers, Porteus 17, fol. 138-140.

21 Lambeth Palace, Fulham Papers, Porteus, 17, fol. 142-144; Tony Claydon, William III and the Godly Revolution, (Cambridge: Cambridge University Press, 1996), 58, 106-108; Sharpe, Rebranding Rule, 367-368; Burrows, Handel and the English Chapel Royal, 29. The 1692 thanksgiving also mentioned a victory by the fleet.

22 The old cathedral had been destroyed in the Great Fire of London (1666). Designed by Christopher Wren, the new cathedral was built between 1675 and 1710.

23 Mears, 'Public Worship and Political Participation in Elizabethan England,' 2-25.

24 Helen Jacobsen, Luxury and Power: the Material World of the Stuart Diplomat, 1660-1714 (Oxford: Oxford University Press, 2012), 91. 
her kingdom. ${ }^{25}$ As the last state thanksgiving had occurred in 1588, Anne gave orders for a 'Committee of the Council' to arrange the first ceremony of state in the new cathedral. ${ }^{26}$ Although in some areas the committee followed the precedent set in 1588 , it was unclear who had overseen the liturgical arrangements for the ceremony. The committee addressed this problem and specified that St Paul's Cathedral would become the 'Queen's Chapel Royal' on the day of thanksgiving. ${ }^{27}$ This meant that the religious service came under the control of the Crown. The evidence suggests that the appointment of the person who would preach the sermon was a decision taken by the government in consultation with the queen and senior clergymen. The Archbishop of Canterbury wrote the form of prayers for the service at St Paul's and the version designed for national distribution. Nonetheless, the queen was in overall charge of these events. The monarch was the head of the Church of England, and Anne was a deeply religious woman, so she took great interest in the form these ceremonies would take. In fact, at times, she exercised considerable control over the proceedings. Anne chose the anthems, examined the prayers to be used, discussed the choice of biblical texts for the sermon, approved the order of service before it went to print, and on at least two occasions chose the men who would preach before her, suggesting a degree of political agency on Anne's part that has hitherto gone largely unnoticed..$^{28}$

Gender historians have long argued that religion provided women from all social levels with a powerful justification for independent action. In times of emergency or instability, religious institutions and ceremonies offered women opportunities to play a public religious role. ${ }^{29}$ In other words, public religion empowered women, and in the case of female rulers, enabled direct political action. ${ }^{30}$ The issue of how to present a female king in wartime presented considerable challenges to Anne and her advisors. To a large extent these difficulties were overcome by the pivotal role the queen played in drawing the

25 By the Queen. A Proclamation, for a Publick Thanksgiving. [3 November 1702] (London, 1702).

26 College of Arms, $\mathrm{M}_{3}$ bis (Ceremonial), last page in the volume (unpaginated).

27 College of Arms, $\mathrm{M}_{3}$ bis (Ceremonial), fol. 36-45, last page in the volume (unpaginated).

$28 H$ HC, Eleventh Report, Appendix Part V, Dartmouth Papers, 315, 15 May 1713, Whitehall: Earl of Dartmouth to the Queen; Lambeth Palace MS 930 (Correspondence), 29 July 1705 Lord Godolphin to Thomas Tenison, Archbishop of Canterbury; Luttrell, vi, 157; Burrows, 34, 36; Hannah Smith, 'Last of all the Heavenly Birth: Queen Anne and Sacral Queenship,' Parliamentary History 28 (2009): 137-149; Gregg, 165.

29 For example see: Merry Wiesner-Hanks, Women and Gender in Early Modern Europe (Cambridge: Cambridge University Press, 2008), 207-251.

$30 \quad$ Wiesner-Hanks, Women and Gender, 208. 
political nation together in the performance of a corporate religious act. But religion was inextricably connected to politics in the early modern period. Disputes over issues such as popery, religious toleration and the practice of occasional conformity by Protestant nonconformists continued to cause controversy in England. Despite the passing of the Act of Toleration (1689), these concerns regularly fuelled debates in parliament and in the press in the opening decade of the eighteenth century. ${ }^{31}$ As outlined above, religious controversies were generally concerned with public policy and practice, what Mark Knights calls 'politicized religion'. ${ }^{32}$ A public religious act by the monarch was a visible indicator of the ruler's commitment to the Church of England. During this period, however, state thanksgivings were also used to promote the Protestant nature of the British monarchy to a wider public, and these grand ceremonies highlighted the queen's commitment to Protestantism, not just the Church of England. By participating in these services at St Paul's, Anne presented herself as powerful wartime leader, emancipated from absolutist monarchical ambitions and committed to parliamentary monarchy. During the sermon clergymen portrayed Anne as being morally and spiritually superior to the 'common enemy' - Louis XIV—and as a Protestant exemplar they promoted her as a symbol of national unity. Aside from giving thanks to God, from the very beginning of the reign, these ceremonies were designed to generate patriotic feelings and encourage loyalty to the post-Glorious Revolution monarchy. Thanksgivings held in the localities enhanced this process.

\section{Military Queenship through Religious Devotion: Queen Anne and the Thanksgivings at St Paul's Cathedral, 1702-8}

On 12 November 1702 Queen Anne led a public thanksgiving at St Paul's Cathedral to offer thanks to God for his 'protection and assistance' in the 'just war' against France. ${ }^{33}$ By 1708 six more of these state occasions had been staged at St. Paul's. All these thanksgivings involved a grand cavalcade to St. Paul's, a royal procession into the cathedral, followed by a long, elaborate religious ceremony attended by the queen. If, as some scholars have claimed, the intention with the first thanksgiving was to emulate Elizabeth I, in terms of

\footnotetext{
31 Melinda Zook, Protestantism, Politics and Women in Britain, 1660-1714 (New York: Palgrave Macmillan, 2013), 8.

Mark Knights, Representation and Misrepresentation in Later Stuart Britain: Partisanship and Political Culture, (Oxford: Oxford University Press, 2004), 18; Zook, Protestantism, 8. 
frequency and political impact, Queen Anne's thanksgivings soon outstripped the Elizabethan version, and arguably nothing since has surpassed them. ${ }^{34}$ Being held in a newly built Protestant cathedral maximised their impact. As the new St Paul's was the first Protestant cathedral to be built in Britain, and in terms of area, one of the largest cathedrals in Europe, the building acquired additional political significance. St Paul's Cathedral symbolised Protestant nationhood and British Imperial power, making it an unparalleled setting for the celebration of military triumph and the affirmation of national unity. ${ }^{35}$

In terms of size and scale, the new cathedral differed considerably from its medieval counterpart. Wren's building offered a vast promenading space, and the choir served as both a seating area and an auditory. Most importantly, in the context of royal ceremony, there was no designated seating for the monarch, as would be found in the chapels royal. When worshipping in the chapels in her palaces, Anne sat in the royal closet and generally was hidden from view by the traverse: a curtained tabernacle-like area that emphasised the sacredness of the monarch. ${ }^{36}$ During the thanksgiving ceremonies at St Paul's, however, Anne was placed on a chair of state, raised on a dais, surmounted by a canopy of state situated in the body of the choir, so in full view of the congregation. ${ }^{37}$ This high level of visibility while in the act of her religious devotions was unusual and commented on by observers. ${ }^{38}$

Once the Queen was installed in her seat in the cathedral, the seating arrangements in the choir allowed for a visualisation of the whole political nation joined together in the worship of God, symbolising as Jonathan Trelawney put it in his 1702 thanksgiving sermon, the '... Act of the Whole Kingdom. ${ }^{39}$ By mirroring the seating arrangements in the House of Lords Anne was visibly part of

34 Bucholz, The Augustan Court, 206-207.

35 Crankshaw, 'Community, City and Nation, 1540-1714,' 45-70.

36 The practice of using the traverse continued at the English court until the end of the eighteenth century. For details see: John Adamson, 'The Tudor and Stuart Courts 1509-1714,' in The Princely Courts of Europe, ed. Adamson, 104; in other courts this area was known variously as the cortina or oratorium.

37 College of Arms ms 3 Bis (1702 proceedings), fol. 36-45; The National Archives, LC 5/70 (Lord Chamberlain: Miscellaneous Records), fol. 194; Lambeth Palace Ms 938 (A Copy of a letter, Sent from a Gentleman in London to His Friend in the Country, Nov. 12th giving some Account of that Day's Solemnity, 1702), fol. 33 .

38 College of Arms ms 3 Bis (1702 proceedings), fol. 36-45; Lambeth Palace ms 938 (A Copy of a letter, Sent from a Gentleman in London to His Friend in the Country, Nov. 12th giving some Account of that Day's Solemnity, 1702), fol. 33 .

39 Johnathan Trelawney, A Sermon Preach'd Before the Queen and Both Houses of Parliament at the Cathedral Church of St Paul's November 12th, 1702 (London, 1702), 34. 
the governing body, her elevated position emphasising her superior status and confirming her central role in parliamentary monarchical government. The close proximity of the members of the House of Commons; nearby, but sitting separately, reiterated the point. The thanksgiving sermons gave aural expression to these symbolic visual forms. A recurring theme was the benefit of 'the body politick', 'our publick councils', 'the balance of government', with Gilbert Burnet referring to the good relationship between the queen and Parliament as 'the harmony between these bodies'. ${ }^{40}$ The way Anne was positioned in the choir also visibly demonstrated her disdain for divine-right theories. Anne may have been the anointed queen of England, but she was made of flesh and blood too, and her location during these thanksgivings, which enabled the audience to see all her physical gestures, demonstrated that fact more clearly than any pronouncement or speech and set her apart from her Stuart ancestors. These events were as infused with political meaning as a debate in Parliament, and the sermon effectively served as a royal speech conveying important political messages on behalf of the queen and her government. Consequently, all the thanksgiving sermons that were preached at St. Paul's were published subsequently. Public Thanksgivings were also reported in the newspapers.

\section{Promoting the Peace and the Protestant Succession: The 1713 Ceremony}

Although all the thanksgivings at St Paul's Cathedral were important, in terms of the queen's own political agenda, the 1713 ceremony was especially significant. Public thanksgivings at St Paul's Cathedral for the celebration of military victories had stopped in 1708 , and the queen had ordered a return to the old system of thanksgiving. The reasons for this change remain unclear, but arguably the withdrawal of this public ceremony was a political manoeuvre by Anne to express her disagreement with the continuation of the war. ${ }^{41}$ It certainly seems

40 George Stanhope, A Sermon... Preach'd Before the Queen the xxvii day of June 1706 (London, 1706), 15; William Talbot, A Sermon Preach'd Before the Queen at the Cathedral Church of St Paul's on May 1 st 1707 (London, 1707), 4; William Fleetwood, A Sermon Preach'd before the Queen at St Paul's, 19 August 1708: the day of thanksgiving for our deliverance from the late invasion and for the victory obtain'd at Audenard (London, 1708), 9; Gilbert Burnet, A Sermon Preach'd before the Queen and the two Houses of Parliament at St Paul's on the 31st December, 1706 the day of thanksgiving for the wonderful successes of the year (London, 1707), 13, 29 .

41 For an overview of possible reasons for the shift see: Burrows, Handel and the English Chapel Royal, 37-39; Farguson, 'Art, Ceremony and the British Monarchy', 247-256. 
notable that despite the absence of the queen, the state thanksgiving staged in 1713 surpassed those held for military victory. Some of the processional elements were aggrandised with lavish firework displays being held in two separate locations, a maypole was set up near the Strand, and the musical elements of the religious ceremony were enhanced. ${ }^{42}$

Music had played an important part in the public thanksgivings held in the previous decade. Various anthems were sung, but Henry Purcell's settings for the Te Deum and Jubilate were the main musical components of these services. For the 1713 Thanksgiving, however, Anne commissioned George Frederic Handel, who at the time served as Kapellmeister to the court in Hanover, to write a new setting. Musicologists have been aware of Anne's involvement in this decision since the 1980 , but the work has generally been analysed from the perspective of Handel's career and the promotion of his operas, therefore the political implications of Anne's patronage have not been fully appreciated. ${ }^{43}$ For an English queen to abandon the work of a renowned native composer for a ceremony closely associated with the British monarchy in favour of music written by a German in the service of the Elector of Hanover, seems extraordinary

42 Evening Post, 7-9 July 1713: 611; British Mercury 3 June 1713: 413; BM 1854, 0614.232; BM 1880, 113.1357; BM 1902, 1011.7977 engraved prints of the fireworks on the River Thames.

Donald Burrows first provided evidence for Anne's involvement in Handel's setting for the Te Deum in his essay entitled 'Handel and Hanover' in Bach, Handel, Scarlatti: tercentenary essays, ed. Peter Williams (Cambridge: Cambridge University Press, 1985), 35-6o. However, in the absence of what Burrows calls 'authority', by the time he published his book on Handel and the Chapel Royal he was reluctant to rely on the evidence produced in his earlier essay as verification of Anne's commission nor on the statement by Thomas Tudway (which in the intervening years Burrows had uncovered) - Professor of Music at the University of Cambridge and a composer and organist - that Handel had composed the new setting 'by the Queen's orders', see: Burrows, Handel and the English Chapel Royal, 78 and n. 8. Given Tudway's close association with Robert Harley and his son Edward, along with his knowledge of contemporary church music, his assertion should be taken seriously. Indeed Tudway repeated the claim in a letter to Humfrey Wanley, the eminent scholar and head of the Harley Library, see: BL Harl. 3782, f. 70 letter from Thomas Tudway to Humfrey Wanley, 23 February, 1716/17; W. Weber, 'Thomas Tudway and the Harleian Collection of Ancient Church Music,' Electronic British Library Journal (1989), article 13, 187-205 [http://www.bl.uk/eblj/1989articles/article13.html], accessed 26 March 2013). It should also be noted that on 28 December 1713 Anne granted Handel an annual pension of $£_{200}$, which adds substance to Tudway's claims, see Burrows, Handel and the English Chapel, 114; Ellen Harris, Handel as Orpheus: Voice and Desire in the Chamber Cantatas (Massachusetts: Harvard University Press, 2001), 186; For a discussion of Handel's operas from a political perspective see: Paul Kléber Monod, 'The Politics of Handel's Early London Operas, 1711-1718,' Journal of Interdisciplinary History 36 (2005): 445-472. 
until we consider the contemporary situation in terms of Anne's desire to promote the peace and her commitment to the Hanoverian succession.

Anne feared that a rival court in London would diminish her political authority; therefore she would not allow any members of the electoral family to visit or reside in England. ${ }^{44}$ But Anne still supported the Protestant succession, and visitors and diplomatic representatives from Hanover were regularly received by the queen at court. These political acts were given additional emphasis by cultural gestures such as the maintenance of Prince George of Denmark's German Chapel at St James' Palace. After his death in 1708, the chapel continued to be staffed by Lutheran preachers from Germany and provided a place of worship for Hanoverian diplomats. ${ }^{45}$ Engaging the services of the 'renowned Mr Handel' should be viewed in a similar light. Handel effectively functioned as a cultural envoy for the Elector, and for Anne to commission a new setting for the Te Deum from Handel—although an aesthetic choice - was laden with political meaning. Handel's association with Anne's court which began soon after his arrival in London in 1710, not only symbolised Anne's commitment to the succession but also promoted cultural unity with Hanover. This was especially important by the time of Handel's second visit to London in 1712. Political relations were strained at this point as both the royal and electoral houses were pursuing policies which benefitted their own territories, but Anne's policy undermined Hanoverian confidence in the queen. The short-term implications of Anne's patronage, which resulted in Handel's dismissal from Hanoverian service shortly before the public thanksgiving in London took place, should not, however, distract us from the considerable benefits to the Hanoverian dynasty in the longer term.

The elector knew Handel was composing a new Te Deum to mark the expected proclamation of peace. In a letter dated 13 January 1713 Thomas Grote, the Hanoverian Resident in London informed the elector of Anne's commission and requested permission for Handel to stay on in London until it was completed. ${ }^{46}$ Presumably, this was granted. This cultural exchange was important for the two dynasties, but in 1713 the main beneficiaries of this political gesture were particular sections of the British public. The formal connection between Handel and the court in Hanover remained intact until June 1713. Through newspaper reports and contemporary accounts of his performances,

44 Gregg, Anne, 366.

45 Susanne Steinmetz, 'The German Churches in London, 1669-1914,' in Germans in Britain Since 1500, ed. Panikos Panayi (London: Hambledon Press, 1996), 57 and n. 29.

46 Letter from Thomas Grote to the Elector of Hanover, 13 January 1713 translated from German and cited by Burrows, 'Handel and Hanover,' 36-6o; citation 42-43. 
Handel's attachment to Hanover was well known among the elite groups who went to the opera but also among those who attended court on the queen's birthday, where for at least two years, possibly three, Handel's music was played. ${ }^{47}$ When we turn to the music commissioned for the 1713 thanksgiving, it is important to note that Handel's Te Deum sounded distinctly different from Purcell's work. Although Handel continued to use the English text and emulated Purcell's style, he provided a 'more complex and expansive treatment' than Purcell, and according to musicologists, added a 'Germanic emphasis' to certain sections. ${ }^{48}$ Overall the music and singing would have sounded more powerful than Purcell's work, and to contemporary ears, fresh and invigorating. Arguably the Utrecht Te Deum was designed to symbolise change: the shift from war to peace, which Anne helped to orchestrate and wanted to endorse but also the eventual shift to a new dynasty. Certainly it seems noteworthy that in September, 1714, on the first Sunday George I attended the Chapel Royal after his arrival in London, Handel's Te Deum was played.9 ${ }^{49}$ This ceremonial performance with musical accompaniment helped to stress continuity during a period of political transition. In 1713, however, Anne and her supporters wanted to advertise the benefits of peace as widely as possibly, but also to highlight her steadfastness to the Hanoverian succession. Handel's music played a part in that process.

In an unprecedented move, once Handel had completed his Te Deum, the work was performed in a series of public rehearsals prior to the thanksgiving service at St Paul's, and these events were reported in the newspapers. Furthermore these concerts were held in buildings that were linked to the British monarchy, and in keeping with the thanksgiving performance, Handel utilised the queen's musicians and choristers. ${ }^{50}$ These gestures further emphasised royal involvement. Early in March the piece was practised twice at St Paul's Cathedral, and later in the month it was rehearsed at the Banqueting House, Whitehall, 'where '[an] abundance of the Nobility and Gentry were

47 Burrows, 'Handel and Hanover,' 35-60; Burrows, Handel and the English Chapel Royal, 75-80; James Winn, 'Style and Politics in the Philips-Handel Ode for Queen Anne's Birthday, 1713,' Music and Letters 89 (2008): 547-561.

48 George Buelow, A History of Baroque Music (Bloomington, Indiana: Indiana University Press, 2004), 485-486.

British Mercury, 22-29 September 1714: 482; Evening Post, 25-28 September 1714; Post Boy 25-28 September 1714: 3025; Harris, Handel as Orpheus, 187; Burrows, Handel and the English Chapel Royal, 116-117; although Burrows acknowledges that the Utrecht Te Deum may have been sung on 26 September, he raises the possibility that the Caroline Te Deum may have been performed instead.

$50 \quad$ Burrows, Handel and the English Chapel Royal, 78. 
present'. ${ }^{\prime 1}$ Another public rehearsal was staged at Whitehall in May. ${ }^{52}$ Although these performances were held in religious buildings, they were removed from a religious ceremony which celebrated an event that some found distasteful. ${ }^{53}$ They also exposed people who supported the peace treaty, but were not among those invited to attend the St Paul's service, to Handel's music. Thus, the audiences in London for these promotional efforts were widened. In terms of publicising the God-given benefits of peace nationally, however, the religious ceremony at St Paul's Cathedral was of paramount importance.

There is no doubt that Anne intended to appear at the service at St Paul's. A new state coach had been built; the queen had sent a message to both Houses of Parliament outlining her intention to attend, and the militia had been commanded to line the processional route. ${ }^{54}$ Due to her physicians' concern about Anne becoming 'fatigued', the queen announced on 6 July that she would not be able to attend the ceremony but instead would offer thanks 'for the blessings of peace in her Chapel at St James's'. ${ }^{55}$ But the queen insisted that 'the House' should still attend the cathedral ceremony, 'with as much Solemnity as if her Majesty' were there in person. ${ }^{56}$ Anne's instructions meant the grand procession still took place. They also ensured the seating in the cathedral would be configured as if the monarch were in attendance. In Anne's absence, a chair of state was placed in the body of the choir as a symbol of the queen's power and authority. ${ }^{57}$ Consequently, the sermon resonated as though the queen were present at the ceremony.

The Bishop of Bath and Wells, George Hooper, preached the sermon on the text of Psalm 122, verse 7: 'Peace be within thy walls and Plenteousness within thy palaces.' ${ }^{58}$ Almost immediately Hooper placed the Peace in a religious framework saying that 'it has pleased God, in his goodness to these kingdoms, to put a happy end to a necessary and victorious ... war. ${ }^{59}$ Hooper went on to state that 'Thanks are justly due to God and the Queen for this great blessing',

$51 \quad$ The Post Boy, 5-7 March 1713: 2781; Burrows, Handel and the English Chapel Royal, 79.

52 British Mercury 13 May 1713: 410; Burrows, Handel and the English Chapel Royal, 79.

53 During this period the Banqueting House served as a royal chapel: Burrows, Handel and the English Chapel Royal, ${ }^{28-529 .}$

54 Burrows, Handel and the English Chapel Royal, 79.

55 Burrows, Handel and the English Chapel Royal, 80.

56 Ibid.

57 John Newman, 'Fittings and Liturgy in post-fire St Paul's', in St Paul's, ed. D. Keene et al., 222-230.

$5^{8}$ George Hooper, A Sermon Preach'd Before Both Houses of Parliament, in the Cathedral Church of St Paul's, on Tuesday July 7, 1713 ... (London: s.n., 1713).

59 Hooper, Sermon, 3. 
highlighting Anne's role as a negotiator in the spiritual peace process. ${ }^{60}$ Hooper acknowledged that at times war may be necessary but went on to say that even in a 'just war...' to persist longer in it than is necessary is to '... begin to war against the gospel', making it clear that an end to the war was necessary on religious grounds. ${ }^{61}$ Hooper then listed the material benefits accruing to the British people from 'this long desired peace., ${ }^{62}$ But Hooper soon turned his attention to the situation 'WITHIN OUR WALLS', and it is at this moment the full political message becomes clear. ${ }^{63}$

By bringing about the peace, Anne 'in her wisdom and goodness [had] secur'd' Britain from her external enemies', but Hooper told his audience that regardless of their 'Religious congregations ... all our domestick contentions and little wars at home should cease... let peace be within your walls' ${ }^{\prime}{ }^{4}$ In other words, now that the war had ended, all Anne's subjects should ensure that Britain became peaceful. Hooper went on to extol the benefits of peace for national unity as 'nothing can be more... destructive of human society, than feuds and animosities when they divide and distract a nation.65 Indeed, for Hooper 'the Calamities of a civil war' were by every means possible 'to be avoided' ${ }^{66}$ There had been calls for national unity before in thanksgiving sermons at St Paul's, but nothing as explicit as Hooper's pronouncements. Equally new, was the idea that the queen could restore 'tranquillity' to the British people only if their 'professions of allegiance', which had first been made at the 'coronation', were at this moment repeated. ${ }^{67}$ These dual aspects reflect the urgent need for Anne to assert her political authority but also to generate a sense of social cohesion. In early modern Europe, 'worldly peace' was believed to be part of a 'universal peace order'. 68 This 'order' had first been revealed in the tranquilitas ordinis, or tranquillity of order, as described by Augustine of Hippo in his treatise De Civitate Dei. ${ }^{69}$ By emphasising Anne's piety and her desire to act in the 'publick good', Hooper was able to call for national unity

\footnotetext{
6o Hooper, Sermon, 19.

61 Hooper, Sermon, 6.

62 Hooper, Sermon, 3.

63 Hooper, Sermon, 12.

64 Hooper, Sermon, 12.

65 Hooper, Sermon, 13-14.

66 Hooper, Sermon, 13-14.

67 Hooper, Sermon, 20-22.

68 Inken Schmidt-Voges, 'Making Peace in Early Modern Europe,' in Peace Was Made Here: The Treaties of Utrecht, Rastatt and Baden, 1713-14. ed. Renger de Bruin and Maarten Brinkman (Petersberg: Michael Imhof Verlag, 2013), 49-59.

69 Schmidt-Voges, 'Making Peace'.
} 
and the maintenance of social order and 'tranquillity' in Anne's name. The idea of Anne as a defender of the national interest found further expression in the medal commissioned by the Crown to commemorate the Treaty of Utrecht. ${ }^{70}$ This medal conflated Anne with Britannia: a female figure with a long-standing history as the personification of the state and used by male and female monarchs to evoke both English and British nationhood. ${ }^{71}$

The Treaty of Utrecht ushered in an era of prosperity for the British people, but French recognition of Anne's rights to the Crown and the legitimacy of the Hanoverian succession meant the treaty also marked the beginning of a period of political transition, which generated great uncertainty about the future of the British monarchy. A Public Thanksgiving was called in order to promote the peace brokered at Utrecht but also to assert Anne's sovereign authority at a moment of political crisis. By focusing on the queen's religious devotion and desire to act in the 'publick good', Hooper presented Anne as a locus for national unity and called for the British people to renew their allegiance to her. The orchestration of the religious ceremonies held in the localities by the queen and her government ensured the majority of her subjects responded to Anne's call for loyalty and peace. For the Tories there were tangible benefits to these politico-religious outpourings. As Britain prepared for a general election in August 1713, it was the peace treaty which dominated prints and pamphlets, and the fact the Tories managed to increase their majority in the Commons by a significant margin may in part be due to the impact of the thanksgiving ceremonies. These ceremonies may also have helped to prevent the descent into civil war and chaos that some contemporaries feared. Historians have rightly examined the forces that caused divisions during this period but have paid little attention to what held society together. It seems likely that during Anne's reign, public thanksgivings, especially the 1713 ceremonies, played a part in that process. Even though she was absent from the service at St Paul's Cathedral, Anne was still presented as a Stuart emancipated from absolutist monarchical ambitions, committed to parliamentary government and removed from party factionalism. Hooper then promoted the queen as a symbol of national

70 BL Add. MS 21238 (Warrant... for the manufacture and distribution of 812 gold medals to commemorate the Peace of Utrecht: 14 July 1713).

71 Maggie Dresser, 'Britannia' in Patriotism and the making and unmaking of British National Identity, volume III, ed. Raphael Samuel (London: Routledge, 1989), 26-49; Roy Matthews, 'Britannia and John Bull: from Birth to Maturity,' The Historian, 62 (2000), 799-820; Anne Helmreich, 'Domesticating Britannia: Representations of the Nation in Punch, 1870-1880,' in Art, Nations and Gender: Ethnic Landscapes, Myths and Mother Figures, ed. Tricia Cusack and Síghle Bhreathnach-Lynch (Aldershot and Burlington, Vermont, 2003), 15-28. 
unity, and the religious setting reinforced these efforts. Although liturgically speaking Public thanksgivings at St Paul's Cathedral were Church of England ceremonies, it was Protestantism that preachers constantly referred to in their sermons. This meant that in 1713 Anne and her supporters could use religion to publicise the benefits of international peace, but also to 'cultivate and promote peace at home. ${ }^{72}$

72 The Examiner Remarks upon Papers and Occurrences 6-10 July 1713: 16. 